\title{
Epigenetics in radiotherapy: Where are we heading?
}

Citation for published version (APA):

Smits, K. M., Melotte, V., Niessen, H. E. C., Dubois, L., Oberije, C., Troost, E. G. C., Starmans, M. H. W., Boutros, P. C., Vooijs, M., van Engeland, M., \& Lambin, P. (2014). Epigenetics in radiotherapy: Where are we heading? Radiotherapy and Oncology, 111(2), 168-177. https://doi.org/10.1016/j.radonc.2014.05.001

Document status and date:

Published: 01/05/2014

DOI:

10.1016/j.radonc.2014.05.001

Document Version:

Publisher's PDF, also known as Version of record

Document license:

Taverne

Please check the document version of this publication:

- A submitted manuscript is the version of the article upon submission and before peer-review. There can be important differences between the submitted version and the official published version of record.

People interested in the research are advised to contact the author for the final version of the publication, or visit the DOI to the publisher's website.

- The final author version and the galley proof are versions of the publication after peer review.

- The final published version features the final layout of the paper including the volume, issue and page numbers.

Link to publication

\footnotetext{
General rights rights.

- You may freely distribute the URL identifying the publication in the public portal. please follow below link for the End User Agreement:

www.umlib.nl/taverne-license

Take down policy

If you believe that this document breaches copyright please contact us at:

repository@maastrichtuniversity.nl

providing details and we will investigate your claim.
}

Copyright and moral rights for the publications made accessible in the public portal are retained by the authors and/or other copyright owners and it is a condition of accessing publications that users recognise and abide by the legal requirements associated with these

- Users may download and print one copy of any publication from the public portal for the purpose of private study or research.

- You may not further distribute the material or use it for any profit-making activity or commercial gain

If the publication is distributed under the terms of Article $25 \mathrm{fa}$ of the Dutch Copyright Act, indicated by the "Taverne" license above, 
Review

\title{
Epigenetics in radiotherapy: Where are we heading?
}

\author{
Kim M. Smits ${ }^{a, *}$, Veerle Melotte ${ }^{b}$, Hanneke E.C. Niessen ${ }^{b}$, Ludwig Dubois ${ }^{a}$, Cary Oberije ${ }^{a}$, \\ Esther G.C. Troost ${ }^{a}$, Maud H.W. Starmans ${ }^{\mathrm{a}, \mathrm{c}}$, Paul C. Boutros ${ }^{\mathrm{c}, \mathrm{d}, \mathrm{e}}$, Marc Vooijs ${ }^{\mathrm{a}}$, Manon van Engeland ${ }^{\mathrm{b}}$, \\ Philippe Lambin ${ }^{\mathrm{a}}$
}

${ }^{a}$ Department of Radiation Oncology (MAASTRO); ${ }^{b}$ Department of Pathology, GROW-School for Oncology and Developmental Biology, Maastricht University Medical Center,

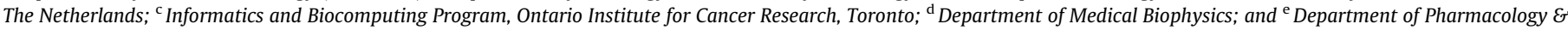
Toxicology, University of Toronto, Canada

\section{A R T I C L E I N F O}

\section{Article history:}

Received 21 May 2013

Received in revised form 17 March 2014

Accepted 1 May 2014

Available online 23 May 2014

\section{Keywords:}

Epigenetic biomarkers

Radiotherapy

DNA methylation

Histone modifications

Hypoxia

\begin{abstract}
A B S T R A C T
Radiotherapy is an important component of anti-cancer treatment. However, not all cancer patients respond to radiotherapy, and with current knowledge clinicians are unable to predict which patients are at high risk of recurrence after radiotherapy. There is therefore an urgent need for biomarkers to guide clinical decision-making.

Although the importance of epigenetic alterations is widely accepted, their application as biomarkers in radiotherapy has not been studied extensively. In addition, it has been suggested that radiotherapy itself introduces epigenetic alterations. As epigenetic alterations can potentially be reversed by drug treatment, they are interesting candidate targets for anticancer therapy or radiotherapy sensitizers. The application of demethylating drugs or histone deacetylase inhibitors to sensitize patients for radiotherapy has been studied in vitro, in vivo as well as in clinical trials with promising results. This review describes the current knowledge on epigenetics in radiotherapy.
\end{abstract}

(c) 2014 Elsevier Ireland Ltd. All rights reserved. Radiotherapy and Oncology 111 (2014) 168-177

\section{Background}

Although radiotherapy (RT) is an important and effective element of current cancer treatment [1], a subgroup of patients does not respond to RT and has progressive disease or a recurrence shortly after treatment ends. As maximal RT dose on the tumor is determined by normal tissue tolerance, increasing radiation dose is often unfeasible as it also increases adverse effects in healthy tissues [2]. Also other efforts to optimize RT, such as precision in dose delivery and optimization of treatment plans, are not beneficial for some patients and large inter-individual differences in treatment response are observed [3]. Cellular RT response is (partly) dependent on the molecular composition of cells, but there is limited evidence that predictive biomarkers can use this altered molecular composition to predict radiosensitivity $[3,4]$. The ability to predict RT response would be a valuable asset to physicians for several reasons [5]. At the moment, prediction of RT outcome is based on clinical parameters, such as tumor stage and grade [6]. Combining several clinical characteristics has led to the development of publicly available predictive models for several cancer types

\footnotetext{
* Corresponding author. Address: Department of Radiation Oncology (MAASTRO), GROW-School for Oncology and Developmental Biology, Maastricht University Medical Center, PO Box 3035, 6202 NA Maastricht, The Netherlands.

E-mail address: kim.smits@maastro.nl (K.M. Smits).
}

(www.predictcancer.org) [7-19]. However, variation in response between patients with identical clinical characteristics indicates that these models can be improved, for example by adding blood-based (e.g. protein), DNA-based/molecular (e.g. epigenetic modifications) or imaging (e.g. hypoxia-imaging) biomarkers [20].

\section{Epigenetic modifications - general introduction}

Gene expression can be influenced by many different aberrations. Among the most studied epigenetic aberrations are DNA methylation and histone modifications which have been shown to have a crucial function in carcinogenesis and tumor progression and are considered potential targets for anticancer therapy and/or treatment sensitizers (Fig. 1). Epigenetics is a rapidly growing research field, and several in-depth reviews on epigenetic alterations are available (e.g. [21-27]).

\section{DNA methylation}

DNA methylation consists of the introduction of a methyl-group (CH3) at the $5^{\prime}$ position of the cytosine base in the DNA, established by DNA methyltransferases (DNMTs) (Fig. 1). Although global hypomethylation is frequently observed in cancer, the best characterized epigenetic modification in malignant cells is 


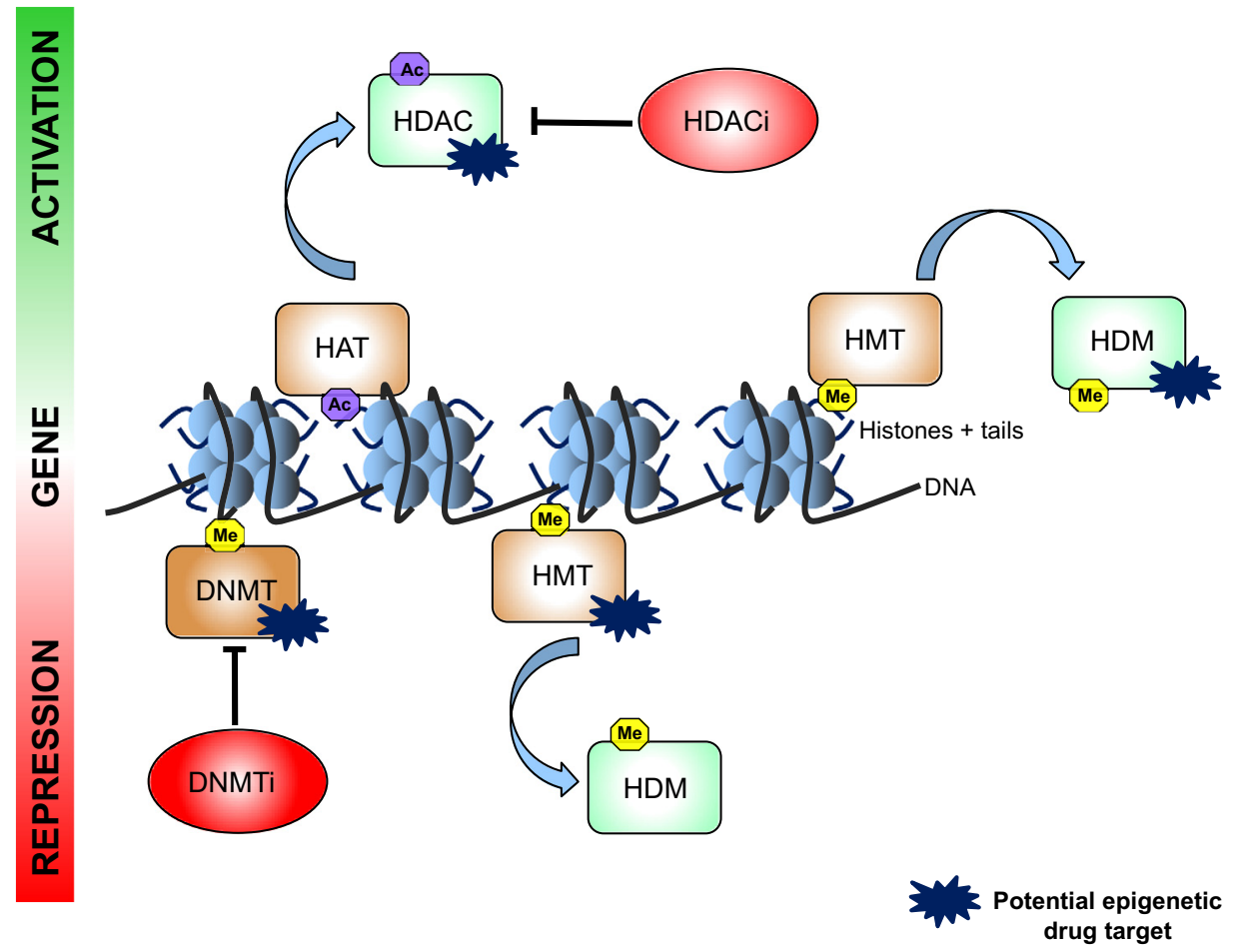

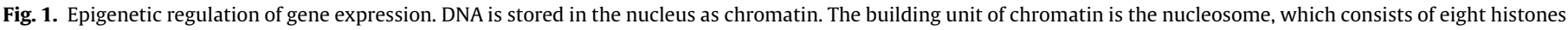

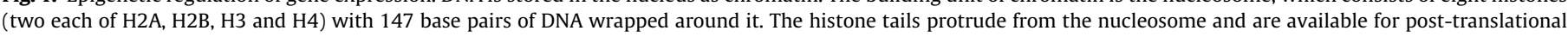

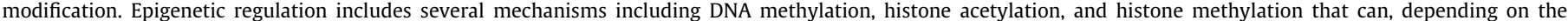

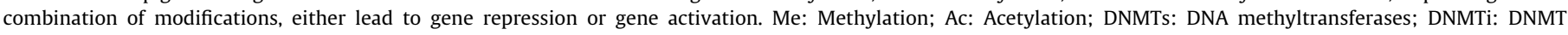
inhibitors; HAT: histone acetyltransferases; HDAC: histone deacetylases; HDACi: HDAC inhibitors; HMT: histone methyltransferases; HDM: histone demethylases.

hypermethylation in $\mathrm{CpG}$ islands (genomic regions containing high amounts of cytosine bases followed by guanine bases) which are present in $70 \%$ of all mammalian promoters [21,22]. However, aberrant methylation has also been found within gene bodies and $\mathrm{CpG}$ shores (conserved sequences upstream or downstream of CpG islands) $[21,28,29]$. Recently, it was recognized that the position of methylation is crucial for the consequences on transcriptional levels [21,30], and the dynamic nature of DNA methylation was confirmed [31,32]. Moreover, other forms of DNA methylation (oxidation derivatives), such as 5-hydroxymethylcytosine $(5 \mathrm{hmC}), 5$-formylcytosine $(5 \mathrm{fC})$ and 5-carboxylcytosin $(5 \mathrm{caC})$, have been identified, emphasizing the complex nature of these epigenetic alterations.

Our knowledge about the methylome has been greatly expanded by whole-genome approaches and it seems clear that both function and influence on transcription vary with the context. These recent developments reveal complex interactions between different molecular markers but will also improve the use of epigenetic biomarkers in cancer [33,34]. Indeed, recent reports have demonstrated that DNA methylation marks can be found in circulating DNA from prostate cancer patients, and can be used to generate accurate, minimally-invasive epigenetic biomarkers [35].

\section{Histone modifications}

Histone modifications can alter electrostatic charges and recruit binding proteins that are frequently part of chromatin remodeling complexes, thereby making the chromatin more or less accessible for other proteins, such as transcription factors. This influences transcription and other DNA-based processes [33]. Currently, 16 types of histone modifications have been detected, the most common ones are acetylation and methylation [33]. To catalyze the addition and removal of histone modifications, several enzymes are involved, e.g. histone acetyltransferases (HATs) and histone deacetylases (HDACs) (Fig. 1). Aberrant histone modification patterns have been reported in several cancer types [36,37], and are suggested as biomarkers of recurrence [38] and survival [39-42].

Cancer genetics and epigenetics have long been considered two separate mechanisms but nowadays it is generally accepted that both act together and take advantage of each other [34]. DNA methylation can be detected and quantified by numerous technologies including genome-wide screening methods as well as locus- or gene-specific high-resolution analysis in different tissue samples and body fluids [43-46] obtained through non-invasive procedures making DNA methylation a very suitable biomarker. $\mathrm{O}^{6}$-methylguanine methyltransferase (MGMT) methylation (to predict treatment response in glioblastoma) and glutathione S-transferase P1 (GSTP1) methylation (to detect prostate cancer) are two examples of promising epigenetic biomarkers proving the applicability of DNA methylation as a biomarker [47-50].

\section{Hypoxia - general introduction}

Low tumoral oxygen levels (hypoxia) are known to decrease the effectiveness of RT [51,52], however, the precise mechanisms causing radioresistance are not yet completely understood [53,54].

RT causes DNA damage either by direct ionization or indirectly by DNA interaction of radicals formed by ionization of water surrounding DNA [55] resulting in DNA single- or double-strand breaks. Oxygen molecules react with these radicals, thereby changing the chemical composition of DNA strand breaks, causing them to be recognized by enzymes of the DNA damage repair (DDR) pathways [56]. Under hypoxic conditions, radicals undergo a chemical reaction with free protons, restoring their original form. This phenomenon counteracts the fixation of DNA damage and is therefore a major cause of radioresistance [56-58]. 
Other possible causes of radioresistance under hypoxic conditions can result from the induction of oxygen-sensitive signaling pathways, such as pathways mediated by (1) the hypoxia-inducible factor family of transcription factors (HIFs, and HIF-1 in particular), (2) unfolded protein response (UPR) or, (3) mammalian target of rapamycin (mTOR) pathway [59]. These pathways affect many biological processes, including mitosis, apoptosis and angiogenesis, some of which are known to influence radiosensitivity [55].

First, the HIF pathway is activated during moderate hypoxia activating cellular processes such as angiogenesis and cell survival. The interplay between HIF-1 and radiosensitivity appears to be complex; some HIF-1-mediated effects enhance radioresistance, others enhance radiosensitivity [55].

Second, under hypoxic conditions, the UPR program is activated by endoplasmatic reticulum (ER) stress sensors in the ER membrane (protein kinase-like ER kinase (PERK)/eukaryotic initiation factor $2 \alpha$ (eIF $2 \alpha$ ), inositol requiring kinase 1 and activating transcription factor 6 ) leading to inhibition of translation and activation of signaling pathways involved in protein folding [60,61]. Recently, especially eIF2 $\alpha$ has been shown to be important for cell survival, and its inhibition was associated with treatment response improvement. eIF $2 \alpha$-deficient cells failed to produce enzymes needed for glutathione synthesis and cysteine uptake leading to elevated reactive oxygen species that are toxic for cells [61]. These results indicate the importance of this pathway in determining treatment response and as a possible target for radiosensitizers [61].

Third, during hypoxia, mTOR activity is reduced preventing the formation of eIF4F translation initiation complex; eventually causing repression of protein synthesis. eIf4E, a limiting factor in the eIF4F complex, has previously been associated with malignancy and poor outcome if overexpressed. Paradoxically, this overexpression is also associated with increased sensitivity to hypoxiainduced cell death and RT in vitro and in vivo, possibly due to a co-overexpression of 4E-BP1 [62].

\section{Epigenetics in radiotherapy}

Despite promising results in other cancer types [21,49,63-67], the usefulness of epigenetic alterations (single marker, marker panels or pathways) as potential prognostic or predictive biomarkers in RT has not been studied extensively (Table 1); available evidence on the connection between epigenetics and radiosensitivity is scarce and mostly based on in vitro or in vivo data $[6,68]$.

\section{Molecular markers}

A well-known example of a predictive epigenetic biomarker is MGMT methylation in glioblastoma [48,49,65]. MGMT encodes for a DNA repair enzyme that counteracts the effect of alkylating treatment by removing alkyl groups from guanine. Moreover, hydroxyl radicals that are generated by radiation induce MGMT expression [69]. Patients with a methylated MGMT promoter have a better survival following adjuvant chemotherapy or RT [70-72]. A recent meta-analysis reports hazard ratios of approximately 0.7 for patients with high-grade glioma receiving RT after surgery. As no survival effect was observed in patients treated with surgery alone, MGMT is probably a predictive biomarker, not a prognostic [70]. In other solid tumors, MGMT methylation has been studied with varying results. In some tumors, such as cervix, MGMT methylation seems to be associated with poor prognosis after (chemo)radiotherapy [63,73-77] whereas no influence on RT outcome was found for other cancers [78]. Although evidence for MGMT methylation as a predictive biomarker seems convincing, the optimal method to assess MGMT methylation has not been established yet and the Level of Evidence is insufficient (below Ia; the level corresponding to evidence from meta-analyses and randomized clinical trials) for its use in current routine clinical practice [47,79].

In addition to MGMT as a possible methylation biomarker in RT, several other markers have been suggested to have a prognostic role. However, evidence is scarce, results often inconsistent, and clinical studies in patient populations are often lacking. For these reasons, none of these markers is expected to be useful in routine clinical practice in the near future. Ataxia Telangiectasia Mutated (ATM) [80,81] methylation has been associated with increased radiosensitivity in vitro [82], but expression is highly heterogeneous and its contribution to radiosensitivity remains questionable [83,84]. The impact of ATM methylation on toxicity has not been studied yet [85]. In addition, some evidence suggests false-positive incidence results for ATM methylation due to non-specific primer design [86]. Other single methylation markers suggested to be associated with poor RT response include RPRM (esophageal cancer patients) [87], RUNX3 (esophageal cancer cell lines) [88], TP73 (cervical cancer patients) [89] and BRCA1 (cervical cancer patients) [73]. In contrast, TIMP3 and CDH1 methylation was associated with a better response to RT in head and neck squamous cell carcinoma

Table 1

Epigenetic modifications associated with radiotherapy (response).

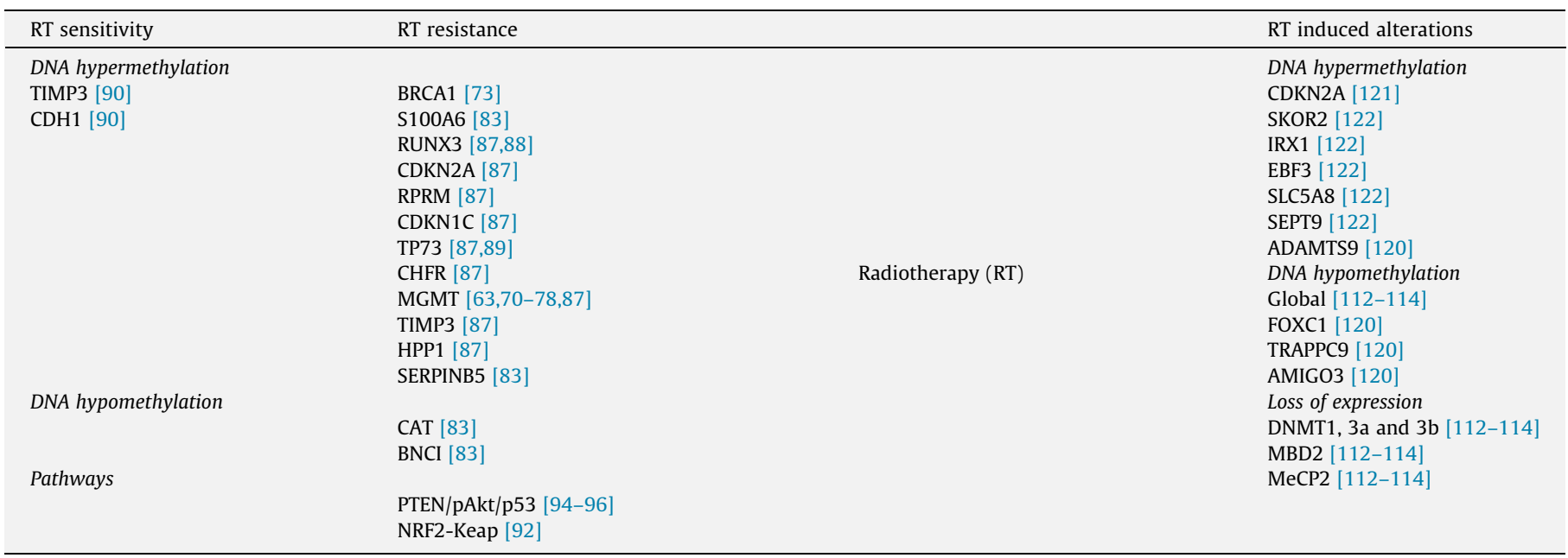


patients [90]. Some of these single markers have been studied within a marker panel (CDKN2A, RPRM, CDKN1C, TP73, RUNX3, CHFR, MGMT, TIMP3 and HPP1) showing decreased methylation in RT responsive esophageal cancer patients [87]. Although these single-marker studies indicate a role of specific epigenetic biomarkers in determining RT response, the prognostic value of these markers has not been validated in large patient populations yet, making them inappropriate for clinical use at the moment.

Only one study has been published using a non-candidate marker approach. In this study, the RT-resistant non-small cell lung cancer H1299 cell line showed a higher proportion of hypermethylation (18.7\%) as compared to the RT-sensitive H460 cell line (15.9\%), 1091 genes were identified as differentially methylated genes, of which 747 genes were hypermethylated and 344 hypomethylated in H1299. Hypermethylated genes were involved in multiple processes, such as cell-cell communication and signal transduction, while hypomethylated genes were mostly involved in transcriptional regulation. Four genes with the most significant differences in methylation between cell lines were studied more extensively, suggesting a role for SERPINB5 and S100A6 hypermethylation and CAT and BNCI hypomethylation in radioresistance. These results suggest that RT response is highly dependent on overall methylation profile of the patient's tumor [83]. Although the results of this study indicate that epigenetic alterations (prior to RT) might be associated with radioresistance, results are derived from in vitro studies, have not been validated in patients yet. In addition, the correlation between methylation and expression has not been studied. It remains uncertain whether observed differences between cell lines are indeed related to radiosensitivity, and not merely the result of comparing two different cell lines.

\section{Molecular pathways}

A recent review indicated that the majority of hypermethylated genes related to RT or chemotherapy outcome, were involved in DDR, WNT-signaling or PI3K/MAPK signaling [68]. Each of these can be activated through many mechanisms, including aberrant DNA methylation, point or structural mutations or inactivation of pathway negative regulators. Nevertheless it can be questioned whether single-gene modifications alone can be responsible for radiosensitivity [91]. Probably, (several) disrupted pathways determine a radiosensitive or -resistant phenotype. Following this hypothesis, several studies investigated dysregulation of specific pathways due to epigenetic events, and their influence on RT response.

In prostate cancer cell lines, the Nrf2-Keap1 pathway, which is activated upon UPR [61], has been reported to be deregulated due to Keap1 inactivation by loss-of-function mutations or promoter CpG hypermethylation, leading to increased Nrf2 expression. Inhibition of the Nrf2-Keap1 pathway has been shown to sensitize radioresistant DU-145 cells [92]. Radioresistant and doxorubicinresistant MCF-7 breast cancer cells (MCF-7/DOX) show lower overall methylation levels as compared to radiosensitive MCF-7 cells. Treatment with methyl-donor S-adenosyl methionine (SAM) resulted in increased radiosensitivity. In contrast, SAM treatment led to a decreased radiosensitivity in MCF-7 cells, possibly due to hypermethylation of specific genes. These results emphasize the fine balance between overall methylation levels, methylation of specific genes and the subsequent radiosensitivity [93]. In oral squamous cell carcinoma, a gene-dosage effect was reported in patients treated with surgery and adjuvant RT; patients had a poorer disease-free survival with increasing activity of the Ras/ PI3K/AKT pathway [94]. Activation of this pathway has been associated with radioresistance in vitro and in vivo [95,96]. The results of these studies clearly indicate that specific pathways (partly) regulated by epigenetic events, can have an effect on radiosensitivity.
The clinical implications of these findings are however less clear at the moment, as it is difficult to manipulate specific pathways in order to improve radiosensitivity.

Despite increasing knowledge on other epigenetic events as histone modifications and micro-RNAs, these phenomena have not yet been assessed for their role in determining RT response.

\section{Hypoxia and epigenetics}

Recent literature describes four views on the extensive interaction between epigenetics and hypoxia [97]. First, expression of von Hippel-Lindau (VHL) and prolyl 4-hydroxylase domain protein 3 (PHD3), two genes that are responsible for the ubiquitination and degradation of HIF in the presence of oxygen, are epigenetically regulated. Silencing of these genes can lead to the formation of transcriptionally active HIF under normoxia.

Second, epigenetic mechanisms maintain a transcriptionally active chromatin confirmation around HIF binding site regions, either through HIF- $1 \alpha$ co-activation or through direct modifications of binding sites, thereby regulating HIF binding. During the initial hypoxic response, epigenetic modifying enzymes, e.g. histone acetyltransferase enzyme $\mathrm{CBP} / \mathrm{p} 300$, are in direct contact with HIF- $1 \alpha$ participating in the co-activation of hypoxia-inducible genes [97]. SRC- 1 and TIF2, both members of the HIF- $1 \alpha$ co-activation complex were also found to have HAT activity [98]. (Functional) DNA methylation within consensus hypoxia response elements has been reported, and it has been shown that hypoxiainduced expression depends on the tissue-specific methylation status [99-101]. As global methylation changes may result from chronic hypoxic conditions, the HIF-dependent transcriptional profile may be determined by the intensity and duration of hypoxia [97].

Third, several histone demethylase genes, including some of the Jumonji family (induced as a consequence of HIF binding during hypoxia) are direct HIF-1 target genes [102]. These findings reveal the possibility of direct hypoxic regulation of histone demethylases, resulting in both active and inactive chromatin states.

Finally, global changes in histone modifications and DNA methylation are observed in response to hypoxia, resulting in transcriptional activation or repression. For example, hypoxia has been shown to increase H3K4me3 (an active mark), decrease H3K27me3 (a repressive mark) and increase H3K27me3 (a repressive mark) [103]. Exposure to anoxia has been described to induce a $15-20 \%$ reduction in DNA methylation [104]. These latter findings indicate that epigenetics has a further important role in the adaptation and survival of cells that is not solely dependent on interaction with HIF. As hypoxia is regarded a major component of determining RT response, growing knowledge on the influence of epigenetics in the hypoxic response emphasizes the importance of epigenetics in RT.

\section{Radiation as a cause of epigenetic alterations}

RT effects on genetic alterations (or vice versa) have been studied extensively [105-111]. The effects on epigenetic alterations however, have been studied less often [1] even though these alterations potentially lead to changes in transcriptional activity and thereby to altered cellular resistance to radiation [112] (Fig. 2, Table 1).

RT causes global hypomethylation in vitro and in vivo, possibly due to a decreased expression of DNMT1, DNMT3a/3b, MeCP2 and MBD2 [112-114]. This effect seems more pronounced after fractionated RT, appears sex- and tissue-specific [115] and is persistent, even after repair of radiation-induced DNA damage [113,116-119]. As global hypomethylation has been linked to 
malignant transformations, radiation-induced DNA hypomethylation may be a marker of oncogenic transformation [116,119]. In addition to global changes, locus-specific alterations, hypo- as well as hypermethylation, have also been reported after radiation [120122 ]. An increase in methylation was observed in ADAMTS9, FOXC1, TRAPPC9 [120] and CDKN2A [121] whereas AMIGO3 [120] showed a decrease in methylation. Interestingly, in vitro studies show that after a recovery period in which cells overcome the radiationinduced growth-arrest, FOXC1 and TRAPPC9 showed a significant methylation loss compared to mock-treated cells. As both genes are involved in apoptosis, this hypomethylation might indicate reduced apoptotic signaling resulting in regrowth of cells after radiation [120].

Other locus-specific methylation changes after radiation have been reported in SKOR2, IRX1, EBF3, SLC5A8 and SEPT9 [122].

Although these results indicate global and locus-specific changes in DNA methylation after radiation, it was only recently revealed that these alterations were indeed enriched in pathways directly involved in radiation responses such as cell cycle regulation, DDR and apoptosis. A recent study using a more epigenome-wide approach identified 15 genes and 23 genes that were differentially methylated after radiation with 2 and 6 Gy respectively. Strikingly, overall methylation patterns appeared to be dose-dependent; cell cycle pathways tended to be hypermethylated directly after $2 \mathrm{~Gy}$ radiation, but hypomethylated at later time points. These patterns were opposite after $6 \mathrm{~Gy}$ radiation and in this case, the moment of switch from hypo- to hypermethylation was associated with a significant arrest in the $G_{2}$ phase of the cell cycle. This suggests a direct correlation between methylation patterns and the biological response to radiation, and implies that epigenetic alterations after radiation are not random. Similarly, a higher radiation dose was associated with higher hypermethylation in apoptosis pathways and an increased senescence-like phenotype. Dose-dependent differences in methylation were however not seen for genes involved in DDR; hypomethylation was the predominant alteration after both low- and high-dose radiation, particularly in NER, HR and NHEJ pathways [112].

As radioresistance has especially been reported in cancer stem cells [123], radiation-induced methylation levels in these cells seem particularly interesting. However, a recent study on mouse embryonic stem cells did not show any changes in DNA methyla- tion levels after radiation [124]. Epigenetic alterations were also observed in offspring of mice exposed to radiation $[125,126]$ indicating that they might be transmitted through the germline, leading to genomic destabilization, and a possible precursor for carcinogenesis [125].

\section{The use of epigenetic drugs}

Based on the previously described results, epigenetic alterations may be considered as potential targets for radiosensitization. This may be achieved by the regulation of chromatin structure modifications, or by epigenetic manipulation of genes involved in cell cycle, apoptosis or DNA repair. Over the past years, many epigenetic drugs have been studied in vitro or in vivo, but with varying results.

\section{HDAC inhibitors}

HDACs remove acetyl groups on histone tails and influence the interaction between DNA molecules, histone proteins and chromatin-associated complexes, resulting in the formation of heterochromatin and transcriptional deactivation. The FDA approved two HDAC inhibitors (HDACi); vorinostat (also known as suberoylanilide hydroxamic acid; SAHA) for the treatment of relapsed and refractory cutaneous T-cell lymphoma $[127,128]$. Additionally, valproic acid (VPA) was FDA approved for the treatment of epilepsy and other seizure disorders, bipolar disorders, anxiety disorders, schizophrenia and migraine headaches [129].

HDAC inhibitors can be divided in four structural classes (shortchain fatty acids, hydroxamic acids, cyclic peptides and benzamides) and affect mostly HDAC class I or II. HDACi predominantly act by inducing differentiation, apoptosis and cell cycle arrest with a preferred cytotoxicity for tumor cells [130]. For all HDACi, radiosensitizing effects have been reported that may either be explained by chromatin conformation or a decreased repair capacity for double-strand breaks [129].

Several studies have suggested that VPA causes radiosensitization in vitro and in vivo [131,132], and clinical trials are currently ongoing. Histone tails in euchromatin undergo hyperacetylation and hypermethylation after VPA treatment, leading to decondensation of these compartments and to an increased number of sites for

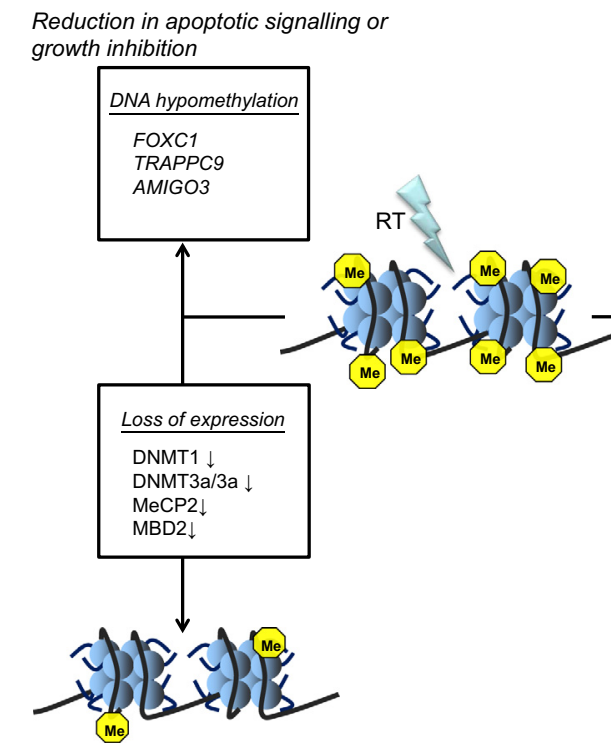

(Global) hypomethylation $\rightarrow$ Genomic Instability
Alterations in TGF $\beta$ signalling or cell cycle pathways

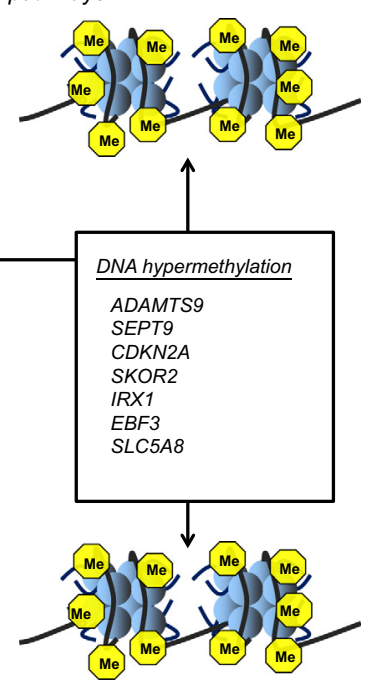

Alterations in hypoxia pathways $\rightarrow$ Altered RS

Fig. 2. Radiotherapy-induced epigenetic alterations. 
radiation-induced DNA damage [132]. However, histone-acetylation and methylation-independent effects are likely to also contribute to radiosensitization [132]. Recent experiments suggest that the radiosensitizing effect of VPA is limited to differentiated cancer cells; in cells expressing cancer stem cell features, VPA even had radioprotective properties [133,134]. Psammaplin A, a natural marine product with cytotoxic effects in several cancer cell lines, also has HDAC activity and enhances radiosensitivity in cell lines possibly by an increase in radiation-induced apoptosis [135]. Other radiosensitizing HDACi include sodium butyrate $(\mathrm{NaB})$, phenylbutyrate, tributyrin, MS275, PCI-24781, AR-42, LBH589 and trichostatin A. These agents sensitize radioresistant cell lines originating from melanoma [136,137], glioma/glioblastoma [138,139], squamous cell [140-142], prostate [138], colon [143,144], cervical [144], breast [145] and hepatocellular carcinoma [146]. However, some HDACis (e.g. SAHA, MS275 and NaB) induce a reduction in double-strand break repair capacity in human fibroblasts obtained from healthy skin emphasizing their potential long-term hazards [129].

In contrast, HDACi have been suggested as radioprotectors for normal tissue when administered topically, possibly due to a decrease in tumor necrosis factor (TNF)- $\alpha$ and transforming growth factor (TGF)- $\beta[147,148]$. Although evidence is limited, it indicates that HDACi might be used as a radioprotector under specific conditions [149].

\section{DNMT inhibitors}

As depletion of DNMTs results in global demethylation [150], different DNMT inhibitors (DNMTi) have been studied as radiosensitizers [128]. Two, 5-aza-cytidine (AZA; azacitidine) and 5-Aza-2'deoxycytidine (DAC; decitabine), have been FDA-approved for treating myelodysplastic syndromes, acute myeloid leukemia and other myeloid syndromes in adults. DNMTi are nucleoside analogs that are incorporated during the S-phase and that irreversibly bind DNMTs to DNA thereby inhibiting them [128]. Because of this, DNMTs are depleted and genes silenced by methylation can be re-expressed. DNMTi are hypothesized to influence radiosensitivity through several mechanisms. First, as DNA synthesis inhibitors, DNMTi can inhibit the repair of RT-induced DNA damage. In addition, they may reduce the number of tumor clonogens by a preferential cytotoxicity to proliferative cells and slow down cell repopulation during RT. Finally, they may trigger apoptosis [2].

Increased radiosensitivity after AZA was observed in vitro for several colorectal [91] and gastric cancer cell lines [151]. Removing AZA returned radiation sensitivity to previous levels, except for HCT116 cells. HCT116 cells deficient in DNMT3b and doubleknock-out HCT116 cells deficient for DNMT1 and DNMT3b showed a trend toward increased RT sensitivity, but this was not seen in cells deficient for DNMT1 alone. As methylation patterns between these cell lines differ, this may indicate differentially active methylation-regulated genes associated with radiosensitivity [91]. However, not all in vitro studies show radiosensitizing effects of AZA [135].

DAC treatment has been associated with increased radiosensitivity in vitro as well, but there was no association between drug-induced epigenetic alterations and radiosensitization. This could indicate that DAC works through mechanisms other than demethylation to influence radiosensitivity [152]. As DAC and AZA are relatively toxic to normal cells, unstable in aqueous solutions and cannot be taken orally, other (less toxic) DNMTi, such as zebularine and 5-fluoro-2'-deoxycytidine have been developed [128] that have also been associated with radiosensitivity $[2,135,153]$.

Despite promising results, caution should be exercised. Most results were generated in in vitro studies and should be validated in vivo. Moreover, the effects of DNMTi combined with RT in healthy tissue have not been assessed and there is conflicting evidence on the (long-term) safety of DNMTi. Demethylating agents also lead to normal tissue hypomethylation and there are indications that this effect can influence radiation-enhanced bystander effects, secondary tumor risk and reactivation of silenced viruses such as Epstein-Barr [91,154]. In vitro and in vivo studies suggest increased mutation frequencies, chromosomal rearrangements, decreased fertility and loss of offspring after azacitidine or decitabine [2]. Interestingly, normal cells seem to have reduced incorporation of epigenetic drugs relative to cancer cells, likely due to their slower dividing rate. This may imply that even low doses will have clinically relevant effects [2,151]. In an attempt to overcome some of the problems of nucleoside DNMT inhibitors, non-nucleoside inhibitors of DNMTs have recently been developed directly binding to DNMT without being incorporated into the DNA. These compounds have demethylating activities in vitro and in vivo and, for some agents, clinical trials are underway [153].

Future studies, in vivo as well as clinical studies are needed to evaluate multiple remaining problems. The optimal treatment schedule for either DNMTi or HDACi has not been established yet. Several schemes are used in studies and therefore it is difficult to compare results. It has been suggested that combining $\mathrm{HDACi}$ and DNMTi is more effective in increasing radiosensitivity as both DNA methylation and histone acetylation are inhibited [150,155]. Even though this approach has been studied in non-RT settings, studies evaluating a combination of epigenetic drugs as radiosensitizers are scarce $[135,155,156]$. Further studies need to elucidate the biological mechanisms of radiosensitivity caused by $\mathrm{HDACi}$ and DNMTi in order to select the most effective radiosensitizer (or perhaps combinations thereof).

\section{The use of epigenetic biomarkers in radiotherapy: future considerations}

Despite growing interest and the growing evidence of an actual link between epigenetic alterations and RT response, there are currently no epigenetic biomarkers for RT response ready for use in daily clinical practice, or even ready for extensive clinical testing. An increasing number of studies focus on epigenetic drugs, either DNMTi or HDACi, as radiosensitizers but it is not known which agent, or which combination is most effective and which dose regimen should be used. Studies evaluating RT-induced normal tissue toxicity after DNMTi or HDACi are scarce. Epigenetic drugs might be effective at low doses only, but these regimens have not been thoroughly tested and the mechanisms of action for many compounds remain unclear $[157,158]$. Further, given the extensive interaction between hypoxia and epigenetics, the microenvironment might be crucial in determining the success of epigenetic drugs. Recent studies suggest an increased efficacy of HDACi and DNMTi under hypoxic conditions [159-162], thereby emphasizing the need to consider the tumor's microenvironment when studying epigenetic drug effects.

Although epigenetic biomarkers encounter some of the same problems as compared to general biomarker studies, they are also confronted with several specific challenges.

In general, similar to genetic biomarker studies, epigenetic biomarker studies are often small and lack validation [6,163]. Singlegene approaches disregard the highly multifactorial nature of radiosensitivity and candidate-marker studies might miss unknown, but highly relevant, biomarkers [6]. Recent technological developments, such as epigenome-wide sequencing, may overcome these problems [64] as no prior assumptions are made on which genes should be studied [6] and several techniques are currently available (for an extensive review, see Ref. [164]), each with 
their corresponding (dis)advantages in terms of costs and covered genomic regions. Without exception, all available whole-genome methylation analyses methods require extensive bioinformatic analysis; a growing number of tools for this are being developed $[164,165]$ but well-qualified and experienced bio-informaticians are crucial to distinguish useful patterns from noise. Indeed, major analytical questions remain unsolved, including the best way to handle heterogeneity in tumor cellularity [166] or to integrate diverse data-normalization protocols [167].

As the probability of false-positive findings is high, genomewide studies need extensive validation and careful experimental design - including up-front power-analyses. For example, methylation profiles are strongly confounded with age, making properly controlled cohorts of particular importance. Internal validation of the utilized sequencing approach and corresponding computational methods is self-explanatory, and is incorporated in most studies. Validation of identified genes or signatures in large, independent study populations, and (if possible) in randomized clinical trials has also been accepted as crucial [165], but the correct protocols remain controversial even in the better-characterized field of mRNA-based biomarkers [168,169]. But studying the biological role of a potential biomarker in vitro and in vivo should also be an important part of biomarker development before use in patient care [64].

A structured approach to identify clinically relevant markers and constructing the most relevant prediction model, as well as the use of whole-epigenome sequencing techniques, might overcome some of the previous, more general problems current studies are facing. But other problems remain. Studies aiming to enhance radiation response by studying epigenetic alterations prediction also encounter several specific challenges. To obtain the most relevant prediction model, not only clinical or epigenetic predictors should be included, but genomic, proteomic and imaging biomarkers should be included as well. As different alterations reflect different tumor development or progression pathways, biomarker signatures monitoring all these different aspects may be more accurate than signatures focusing on one biomarker type exclusively.

It is becoming increasingly clear that methylation within promoter CpG islands is not random, only methylation of specific loci (core regions) can be regarded as functional, i.e. crucial for transcriptional repression [170]. Identifying the core regions regulating gene expression is therefore crucial when studying the clinical value of DNA methylation.

Along this line, the location of the primers used to measure DNA methylation seems critical for the final conclusions of a study $[64,170]$. Optimal primer design to ensure evaluation of the most relevant core regions is therefore one of the most important tasks when designing epigenetic biomarker studies that aim to obtain reliable clinical results. Core regions have also been observed outside the transcription start site region suggesting that larger regions should be evaluated when studying the methylation status of genes [170]. In addition, relevant methylation can occur in regions with low CpG density, CpG island shores [171] and gene clusters can become silenced by long-range epigenetic silencing. This global gene silencing can simultaneously inactivate large regions of the genome [170,172]. These recent discoveries indicate that the mechanism of gene silencing by DNA methylation is much more complex than initially thought and genes previously disregarded as potential epigenetic biomarkers may in fact be relevant when taking the location of methylation into account.

Recent discoveries of alterations such as $5 \mathrm{hmC}, 5 \mathrm{fC}$ and $5 \mathrm{caC}$ add another layer of complexity as current techniques cannot easily distinguish between different cytosine modifications. Nevertheless, epigenetic biomarkers could act as important complementary markers that, combined with clinical variables, blood-based and imaging biomarkers, can greatly improve prediction models for RT.

\section{Conclusion}

Despite the increasing number of studies describing an association between DNA methylation and RT response, many questions remain unanswered. There is currently no DNA methylation marker, or marker panel, that can predict RT response. Other epigenetic markers, such as histone modifications and miRNAs have not yet been evaluated for their influence on RT response. In addition, radiation can also cause epigenetic alterations. Although several studies have reported this, the clinical impact (if any) of this observation is not clear. It can be hypothesized that RT-induced epigenetic aberrations influence treatment outcome and should therefore be monitored. Even though underlying biological mechanisms have not been elucidated yet, a growing number of studies focused on clinical applicability of epigenetic drugs as anticancer treatments or radio sensitizers. None of these drugs have been approved for this application yet but results seem promising and it may only be a matter of time before the first epigenetic radiosensitizer is introduced.

\section{Conflict of interest statement}

The authors declare that they have no conflicts of interest.

\section{References}

[1] Merrifield M, Kovalchuk O. Epigenetics in radiation biology: a new research frontier. Front Genet 2013;4:40.

[2] Gravina GL, Festuccia C, Marampon F, et al. Biological rationale for the use of DNA methyltransferase inhibitors as new strategy for modulation of tumor response to chemotherapy and radiation. Mol Cancer 2010;9:305.

[3] Yaromina A, Krause M, Baumann M. Individualization of cancer treatment from radiotherapy perspective. Mol Oncol 2012:6:211-21.

[4] Popanda O, Marquardt JU, Chang-Claude J, Schmezer P. Genetic variation in normal tissue toxicity induced by ionizing radiation. Mutat Res 2009;667: 58-69.

[5] Haustermans K, Debucquoy A, Lambrecht M. The ESTRO Breur Lecture 2010: toward a tailored patient approach in rectal cancer. Radiother Oncol 2011;100:15-21.

[6] Begg AC. Predicting response to radiotherapy: evolutions and revolutions. Int J Radiat Biol 2009;85:825-36.

[7] Dehing-Oberije C, De Ruysscher D, van der Weide H, et al. Tumor volume combined with number of positive lymph node stations is a more important prognostic factor than TNM stage for survival of non-small-cell lung cancer patients treated with (chemo)radiotherapy. Int J Radiat Oncol Biol Phys 2008;70:1039-44.

[8] Dehing-Oberije C, Yu S, De Ruysscher D, et al. Development and external validation of prognostic model for 2-year survival of non-small-cell lung cancer patients treated with chemoradiotherapy. Int J Radiat Oncol Biol Phys 2009;74:355-62.

[9] Dehing-Oberije C, De Ruysscher D, van Baardwijk A, Yu S, Rao B, Lambin P. The importance of patient characteristics for the prediction of radiation-induced lung toxicity. Radiother Oncol 2009;91:421-6.

[10] Marks LB, Bentzen SM, Deasy JO, et al. Radiation dose-volume effects in the lung. Int J Radiat Oncol Biol Phys 2010;76:S70-6.

[11] Dehing-Oberije C, De Ruysscher D, Petit S, et al. Development, external validation and clinical usefulness of a practical prediction model for radiation-induced dysphagia in lung cancer patients. Radiother Oncol 2010;97:455-61.

[12] van Stiphout RG, Lammering G, Buijsen J, et al. Development and external validation of a predictive model for pathological complete response of rectal cancer patients including sequential PET-CT imaging. Radiother Oncol 2011;98:126-33.

[13] Valentini V, van Stiphout RG, Lammering G, et al. Nomograms for predicting local recurrence, distant metastases, and overall survival for patients with locally advanced rectal cancer on the basis of European randomized clinical trials. J Clin Oncol 2011;29:3163-72.

[14] Egelmeer AG, Velazquez ER, de Jong JM, et al. Development and validation of a nomogram for prediction of survival and local control in laryngeal carcinoma patients treated with radiotherapy alone: a cohort study based on 994 patients. Radiother Oncol 2011;100:108-15.

[15] Christianen ME, Schilstra C, Beetz I, et al. Predictive modelling for swallowing dysfunction after primary (chemo)radiation: results of a prospective observational study. Radiother Oncol 2012;105:107-14 
[16] Ramaekers BL, Grutters JP, Pijls-Johannesma M, Lambin P, Joore MA, Langendijk JA. Protons in head-and-neck cancer: bridging the gap of evidence. Int J Radiat Oncol Biol Phys 2013;85:1282-8.

[17] Ramaekers BL, Joore MA, Grutters JP, et al. The impact of late treatmenttoxicity on generic health-related quality of life in head and neck cancer patients after radiotherapy. Oral Oncol 2011;47:768-74.

[18] Ramaekers BL, Pijls-Johannesma M, Joore MA, et al. Systematic review and meta-analysis of radiotherapy in various head and neck cancers: comparing photons, carbon-ions and protons. Cancer Treat Rev 2011;37: $185-201$.

[19] van der Laan HP, van de Water TA, van Herpt HE, et al. The potential of intensity-modulated proton radiotherapy to reduce swallowing dysfunction in the treatment of head and neck cancer: a planning comparative study. Acta Oncol 2013;52:561-9.

[20] Rodemann HP, Wouters BG. Molecular and translational radiation biology/ oncology: what's up? Radiother Oncol 2011;99:257-61.

[21] van Engeland M, Derks S, Smits KM, Meijer GA, Herman JG. Colorectal cancer epigenetics: complex simplicity. J Clin Oncol 2011;29:1382-91.

[22] Feinberg AP, Tycko B. The history of cancer epigenetics. Nat Rev Cancer 2004;4:143-53.

[23] Jones PA, Laird PW. Cancer epigenetics comes of age. Nat Genet 1999;21: 163-7.

[24] Wolffe AP, Matzke MA. Epigenetics: regulation through repression. Science 1999;286:481-6.

[25] Baylin S, Bestor TH. Altered methylation patterns in cancer cell genomes: cause or consequence? Cancer Cell 2002;1:299-305.

[26] Laird PW. Cancer epigenetics. Hum Mol Genet 2005;14:R65-76.

[27] Esteller M. Epigenetics in cancer. N Engl J Med 2008;358:1148-59.

[28] Baylin SB, Esteller M, Rountree MR, Bachman KE, Schuebel K, Herman JG. Aberrant patterns of DNA methylation, chromatin formation and gene expression in cancer. Hum Mol Genet 2001;10:687-92.

[29] Esteller M, Fraga MF, Paz MF, et al. Cancer epigenetics and methylation. Science 2002;297:1807-8. discussion 1807-1808.

[30] Jones PA. Functions of DNA methylation: islands, start sites, gene bodies and beyond. Nat Rev Genet 2012;13:484-92.

[31] Guo JU, Su Y, Zhong C, Ming GL, Song H. Emerging roles of TET proteins and 5hydroxymethylcytosines in active DNA demethylation and beyond. Cell Cycle 2011;10:2662-8

[32] Branco MR, Ficz G, Reik W. Uncovering the role of 5-hydroxymethylcytosine in the epigenome. Nat Rev Genet 2012:13:7-13.

[33] Dawson MA, Kouzarides T. Cancer epigenetics: from mechanism to therapy. Cell 2012;150:12-27.

[34] You JS, Jones PA. Cancer genetics and epigenetics: two sides of the same coin? Cancer Cell 2012;22:9-20.

[35] Cortese R, Kwan A, Lalonde E, et al. Epigenetic markers of prostate cancer in plasma circulating DNA. Hum Mol Genet 2012;21:3619-31.

[36] Sandoval J, Esteller M. Cancer epigenomics: beyond genomics. Curr Opin Genet Dev 2012;22:50-5.

[37] Fraga MF, Ballestar E, Villar-Garea A, et al. Loss of acetylation at Lys16 and trimethylation at Lys20 of histone $\mathrm{H} 4$ is a common hallmark of human cancer. Nat Genet 2005;37:391-400.

[38] Seligson DB, Horvath S, Shi T, et al. Global histone modification patterns predict risk of prostate cancer recurrence. Nature 2005;435:1262-6.

[39] Barlesi F, Giaccone G, Gallegos-Ruiz MI, et al. Global histone modifications predict prognosis of resected non small-cell lung cancer. J Clin Oncol 2007;25:4358-64.

[40] Barbisan F, Mazzucchelli R, Santinelli A, et al. Immunohistochemical evaluation of global DNA methylation and histone acetylation in papillary urothelial neoplasm of low malignant potential. Int J Immunopathol Pharmacol 2008;21:615-23.

[41] Seligson DB, Horvath S, McBrian MA, et al. Global levels of histone modifications predict prognosis in different cancers. Am J Pathol 2009; 174:1619-28.

[42] Elsheikh SE, Green AR, Rakha EA, et al. Global histone modifications in breast cancer correlate with tumor phenotypes, prognostic factors, and patient outcome. Cancer Res 2009;69:3802-9.

[43] Garcia-Baquero R, Puerta P, Beltran M, et al. Methylation of a novel panel of tumor suppressor genes in urine moves forward non-invasive diagnosis and prognosis in bladder cancer: a two center prospective study. J Urol 2013; 190(2):723-30.

[44] Van De Voorde L, Speeckaert R, Van Gestel D, et al. DNA methylation-based biomarkers in serum of patients with breast cancer. Mutat Res 2012;751: 304-25.

[45] Glockner SC, Dhir M, Yi JM, et al. Methylation of TFPI2 in stool DNA: a potential novel biomarker for the detection of colorectal cancer. Cancer Res 2009;69:4691-9.

[46] Suijkerbuijk KP, van der Wall E, van Vooijs M, Diest PJ. Molecular analysis of nipple fluid for breast cancer screening. Pathobiology 2008;75:149-52.

[47] Berghoff AS, Preusser M. Clinical neuropathology practice guide 06-2012: MGMT testing in elderly glioblastoma patients - yes, but how? Clin Neuropathol 2012;31:405-8.

[48] Esteller M, Garcia-Foncillas J, Andion E, et al. Inactivation of the DNA-repair gene MGMT and the clinical response of gliomas to alkylating agents. N Engl J Med 2000;343:1350-4.

[49] Hegi ME, Diserens AC, Gorlia T, et al. MGMT gene silencing and benefit from temozolomide in glioblastoma. N Engl J Med 2005;352:997-1003.
[50] Esteller M, Corn PG, Urena JM, Gabrielson E, Baylin SB, Herman JG. Inactivation of glutathione S-transferase P1 gene by promoter hypermethylation in human neoplasia. Cancer Res 1998;58:4515-8.

[51] Overgaard J. Hypoxic modification of radiotherapy in squamous cell carcinoma of the head and neck - a systematic review and meta-analysis. Radiother Oncol 2011;100:22-32.

[52] Thorwarth D, Alber M. Implementation of hypoxia imaging into treatment planning and delivery. Radiother Oncol 2010;97:172-5.

[53] Starmans MH, Chu KC, Haider S, et al. The prognostic value of temporal in vitro and in vivo derived hypoxia gene-expression signatures in breast cancer. Radiother Oncol 2012;102:436-43.

[54] Seigneuric R, Starmans MH, Fung G, et al. Impact of supervised gene signatures of early hypoxia on patient survival. Radiother Oncol 2007;83: 374-82.

[55] Moeller BJ, Richardson RA, Dewhirst MW. Hypoxia and radiotherapy: opportunities for improved outcomes in cancer treatment. Cancer Metasta Rev 2007;26:241-8.

[56] Horsman MR, Wouters BG, Joiner MC, Overgaard J. Basic clinical radiobiology. In: Joiner MC, van der Kogel A, editors. The oxygen effect and fractionated radiotherapy. London: Hodder Arnold; 2009. p. 207-16.

[57] Overgaard J. Hypoxic radiosensitization: adored and ignored. J Clin Oncol 2007;25:4066-74.

[58] Hockel M, Vaupel P. Tumor hypoxia: definitions and current clinical, biologic, and molecular aspects. J Natl Cancer Inst 2001;93:266-76.

[59] Wouters BG, Koritzinsky M. Hypoxia signalling through mTOR and the unfolded protein response in cancer. Nat Rev Cancer 2008;8:851-64.

[60] Koumenis C, Wouters BG. "Translating" tumor hypoxia: unfolded protein response (UPR)-dependent and UPR-independent pathways. Mol Cancer Res 2006; 4:423-36.

[61] Rouschop KM, Dubois LJ, Keulers TG, et al. PERK/eIF2alpha signaling protects therapy resistant hypoxic cells through induction of glutathione synthesis and protection against ROS. Proc Natl Acad Sci U S A 2013;110:4622-7.

[62] Rouschop KM, Dubois L, Schaaf MB, et al. Deregulation of cap-dependent mRNA translation increases tumour radiosensitivity through reduction of the hypoxic fraction. Radiother Oncol 2011;99:385-91.

[63] Smits KM, Cleven AH, Weijenberg MP, et al. Pharmacoepigenomics in colorectal cancer: a step forward in predicting prognosis and treatment response. Pharmacogenomics 2008;9:1903-16.

[64] Draht MX, Riedl RR, Niessen H, et al. Promoter CpG island methylation markers in colorectal cancer: the road ahead. Epigenomics 2012:4:179-94.

[65] Hegi ME, Liu L, Herman JG, et al. Correlation of O6-methylguanine methyltransferase (MGMT) promoter methylation with clinical outcomes in glioblastoma and clinical strategies to modulate MGMT activity. J Clin Oncol 2008:26:4189-99.

[66] van Vlodrop IJ, Baldewijns MM, Smits KM, et al. Prognostic significance of Gremlin1 (GREM1) promoter CpG island hypermethylation in clear cell renal cell carcinoma. Am J Pathol 2010;176:575-84.

[67] Yi JM, Dhir M, Van Neste L, et al. Genomic and epigenomic integration identifies a prognostic signature in colon cancer. Clin Cancer Res $2011 ; 17: 1535-45$

[68] Roossink F, de Jong S, Wisman GB, van der Zee AG, Schuuring E. DNA hypermethylation biomarkers to predict response to cisplatin treatment, radiotherapy or chemoradiation: the present state of art. Cell Oncol (Dordr) 2012;35:231-41.

[69] Chan CL, Wu Z, Eastman A, Bresnick E. Irradiation-induced expression of O6methylguanine-DNA methyltransferase in mammalian cells. Cancer Res 1992;52:1804-9.

[70] Olson RA, Brastianos PK, Palma DA. Prognostic and predictive value of epigenetic silencing of MGMT in patients with high grade gliomas: a systematic review and meta-analysis. J Neurooncol 2011;105:325-35.

[71] Rivera AL, Pelloski CE, Gilbert MR, et al. MGMT promoter methylation is predictive of response to radiotherapy and prognostic in the absence of adjuvant alkylating chemotherapy for glioblastoma. Neuro Oncol 2010;12: 116-21.

[72] Niyazi M, Schnell O, Suchorska B, et al. FET-PET assessed recurrence pattern after radio-chemotherapy in newly diagnosed patients with glioblastoma is influenced by MGMT methylation status. Radiother Oncol 2012;104:78-82.

[73] Narayan G, Arias-Pulido $\mathrm{H}$, Koul $\mathrm{S}$, et al. Frequent promoter methylation of CDH1, DAPK, RARB, and HIC1 genes in carcinoma of cervix uteri: its relationship to clinical outcome. Mol Cancer 2003;2:24.

[74] Bae SI, Lee HS, Kim SH, Kim WH. Inactivation of O6-methylguanine-DNA methyltransferase by promoter $\mathrm{CpG}$ island hypermethylation in gastric cancers. Br J Cancer 2002;86:1888-92.

[75] Esteller M, Gaidano G, Goodman SN, et al. Hypermethylation of the DNA repair gene $\mathrm{O}(6)$-methylguanine DNA methyltransferase and survival of patients with diffuse large B-cell lymphoma. J Natl Cancer Inst 2002;94: 26-32.

[76] Baumann S, Keller G, Puhringer F, et al. The prognostic impact of O6methylguanine-DNA methyltransferase (MGMT) promotor hypermethylation in esophageal adenocarcinoma. Int J Cancer 2006;119:264-8.

[77] Cayre A, Penault-Llorca F, De Latour M, et al. O(6)-methylguanine-DNA methyl transferase gene expression and prognosis in breast carcinoma. Int J Oncol 2002;21:1125-31.

[78] Hashimoto K, Narita Y, Matsushita Y, et al. Methylation status of O6methylguanine-DNA-methyl transferase promoter region in non-small-cell lung cancer patients with brain metastasis. Clin Transl Oncol 2012;14:31-5. 
[79] Berghoff AS, Stefanits H, Heinzl H, Preusser M. Clinical neuropathology practice news 4-2012: levels of evidence for brain tumor biomarkers. Clin Neuropathol 2012;31:206-9.

[80] Lavin MF. Radiosensitivity and oxidative signalling in ataxia telangiectasia: an update. Radiother Oncol 1998;47:113-23.

[81] Lobrich M, Jeggo PA. The two edges of the ATM sword: co-operation between repair and checkpoint functions. Radiother Oncol 2005;76:112-8.

[82] Kim WJ, Vo QN, Shrivastav M, Lataxes TA, Brown KD. Aberrant methylation of the ATM promoter correlates with increased radiosensitivity in a human colorectal tumor cell line. Oncogene 2002;21:3864-71.

[83] Kim EH, Park AK, Dong SM, Ahn JH, Park WY. Global analysis of CpG methylation reveals epigenetic control of the radiosensitivity in lung cancer cell lines. Oncogene 2010;29:4725-31.

[84] Roy K, Wang L, Makrigiorgos GM, Price BD. Methylation of the ATM promoter in glioma cells alters ionizing radiation sensitivity. Biochem Biophys Res Commun 2006;344:821-6.

[85] Tanteles GA, Murray RJ, Mills J, et al. Variation in telangiectasia predisposing genes is associated with overall radiation toxicity. Int J Radiat Oncol Biol Phys 2012:84:1031-6.

[86] Brandes JC, Carraway H, Herman JG. Optimal primer design using the novel primer design program: MSPprimer provides accurate methylation analysis of the ATM promoter. Oncogene 2007;26:6229-37.

[87] Hamilton JP, Sato F, Greenwald BD, et al. Promoter methylation and response to chemotherapy and radiation in esophageal cancer. Clin Gastroenterol Hepatol 2006;4:701-8.

[88] Sakakura C, Miyagawa K, Fukuda KI, et al. Frequent silencing of RUNX3 in esophageal squamous cell carcinomas is associated with radioresistance and poor prognosis. Oncogene 2007;26:5927-38.

[89] Liu SS, Leung RC, Chan KY, et al. P73 expression is associated with the cellular radiosensitivity in cervical cancer after radiotherapy. Clin Cancer Res 2004;10:3309-16.

[90] De Schutter H, Geeraerts H, Verbeken E, Nuyts S. Promoter methylation of TIMP3 and CDH1 predicts better outcome in head and neck squamous cell carcinoma treated by radiotherapy only. Oncol Rep 2009;21:507-13.

[91] Hofstetter B, Niemierko A, Forrer C, et al. Impact of genomic methylation on radiation sensitivity of colorectal carcinoma. Int J Radiat Oncol Biol Phys 2010;76:1512-9.

[92] Zhang P, Singh A, Yegnasubramanian S, et al. Loss of Kelch-like ECHassociated protein 1 function in prostate cancer cells causes chemoresistance and radioresistance and promotes tumor growth. Mol Cancer Ther 2010;9:336-46.

[93] Luzhna L, Kovalchuk O. Modulation of DNA methylation levels sensitizes doxorubicin-resistant breast adenocarcinoma cells to radiation-induced apoptosis. Biochem Biophys Res Commun 2010;392:113-7.

[94] Huang KH, Huang SF, Chen IH, Liao CT, Wang HM, Hsieh LL. Methylation of RASSF1A, RASSF2A, and HIN-1 is associated with poor outcome after radiotherapy, but not surgery, in oral squamous cell carcinoma. Clin Cancer Res 2009;15:4174-80.

[95] Gupta AK, Bakanauskas VJ, Cerniglia GJ, et al. The Ras radiation resistance pathway. Cancer Res 2001;61:4278-82.

[96] Gupta AK, Cerniglia GJ, Mick R, et al. Radiation sensitization of human cancer cells in vivo by inhibiting the activity of PI3K using LY294002. Int J Radiat Oncol Biol Phys 2003;56:846-53.

[97] Watson JA, Watson CJ, McCann A, Baugh J. Epigenetics, the epicenter of the hypoxic response. Epigenetics 2010;5:293-6.

[98] Carrero P, Okamoto K, Coumailleau P, O’Brien S, Tanaka H, Poellinger L. Redox-regulated recruitment of the transcriptional coactivators CREBbinding protein and SRC-1 to hypoxia-inducible factor 1alpha. Mol Cell Biol 2000;20:402-15.

[99] Rossler J, Stolze I, Frede S, et al. Hypoxia-induced erythropoietin expression in human neuroblastoma requires a methylation free HIF-1 binding site. J Cell Biochem 2004;93:153-61.

[100] Wenger RH, Kvietikova I, Rolfs A, Camenisch G, Gassmann M. Oxygenregulated erythropoietin gene expression is dependent on a $\mathrm{CpG}$ methylation-free hypoxia-inducible factor-1 DNA-binding site. Eur J Biochem 1998;253:771-7.

[101] Raspaglio G, Filippetti F, Prislei S, et al. Hypoxia induces class III beta-tubulin gene expression by HIF-1alpha binding to its $3^{\prime}$ flanking region. Gene 2008;409:100-8.

[102] Lendahl U, Lee KL, Yang H, Poellinger L. Generating specificity and diversity in the transcriptional response to hypoxia. Nat Rev Genet 2009;10:821-32.

[103] Johnson AB, Denko N, Barton MC. Hypoxia induces a novel signature of chromatin modifications and global repression of transcription. Mutat Res 2008;640:174-9.

[104] Shahrzad S, Bertrand K, Minhas K, Coomber BL. Induction of DNA hypomethylation by tumor hypoxia. Epigenetics 2007;2:119-25.

[105] Andreassen CN, Alsner J. Genetic variants and normal tissue toxicity after radiotherapy: a systematic review. Radiother Oncol 2009;92:299-309.

[106] De Ruysscher D, Severin D, Barnes E, et al. First report on the patient database for the identification of the genetic pathways involved in patients overreacting to radiotherapy: GENEPI-II. Radiother Oncol 2010;97:36-9.

[107] Andreassen CN. Searching for genetic determinants of normal tissue radiosensitivity - are we on the right track? Radiother Oncol 2010;97:1-8.

[108] Andreassen CN, Alsner J, Overgaard J. Does variability in normal tissue reactions after radiotherapy have a genetic basis - where and how to look for it? Radiother Oncol 2002;64:131-40.
[109] Hendry JH. Genomic instability: potential contributions to tumour and normal tissue response, and second tumours, after radiotherapy. Radiother Oncol 2001;59:117-26

[110] Guerra JL, Gomez D, Wei Q et al. Association between single nucleotide polymorphisms of the transforming growth factor beta 1 gene and the risk of severe radiation esophagitis in patients with lung cancer. Radiother Oncol 2012;105:299-304.

[111] Baumann M, Holscher T, Begg AC. Towards genetic prediction of radiation responses: ESTRO's GENEPI project. Radiother Oncol 2003;69:121-5.

[112] Antwih DA, Gabbara KM, Lancaster WD, Ruden DM, Zielske SP. Radiationinduced epigenetic DNA methylation modification of radiation-response pathways. Epigenetics 2013;8:839-48.

[113] Pogribny I, Koturbash I, Tryndyak V, et al. Fractionated low-dose radiation exposure leads to accumulation of DNA damage and profound alterations in DNA and histone methylation in the murine thymus. Mol Cancer Res 2005;3:553-61.

[114] Raiche J, Rodriguez-Juarez R, Pogribny I, Kovalchuk O. Sex- and tissue-specific expression of maintenance and de novo DNA methyltransferases upon low dose X-irradiation in mice. Biochem Biophys Res Commun 2004:325:39-47.

[115] Koturbash I, Zemp F, Kolb B, Kovalchuk O. Sex-specific radiation-induced microRNAome responses in the hippocampus, cerebellum and frontal cortex in a mouse model. Mutat Res 2011;722:114-8.

[116] Koturbash I, Pogribny I, Kovalchuk O. Stable loss of global DNA methylation in the radiation-target tissue - a possible mechanism contributing to radiation carcinogenesis? Biochem Biophys Res Commun 2005;337:526-33.

[117] Koturbash I, Boyko A, Rodriguez-Juarez R, et al. Role of epigenetic effectors in maintenance of the long-term persistent bystander effect in spleen in vivo. Carcinogenesis 2007;28:1831-8.

[118] Ilnytskyy Y, Koturbash I, Kovalchuk O. Radiation-induced bystander effects in vivo are epigenetically regulated in a tissue-specific manner. Environ Mo Mutagen 2009;50:105-13.

[119] Loree J, Koturbash I, Kutanzi K, Baker M, Pogribny I, Kovalchuk O. Radiationinduced molecular changes in rat mammary tissue: possible implications for radiation-induced carcinogenesis. Int J Radiat Biol 2006;82:805-15.

[120] Kuhmann C, Weichenhan D, Rehli M, Plass C, Schmezer P, Popanda O. DNA methylation changes in cells regrowing after fractioned ionizing radiation. Radiother Oncol 2011:101:116-21.

[121] Kovalchuk O, Burke P, Besplug J, Slovack M, Filkowski J, Pogribny I. Methylation changes in muscle and liver tissues of male and female mice exposed to acute and chronic low-dose X-ray-irradiation. Mutat Res 2004:548:75-84.

[122] Bennett KL, Lee W, Lamarre E, et al. HPV status-independent association of alcohol and tobacco exposure or prior radiation therapy with promoter methylation of FUSSEL18, EBF3, IRX1, and SEPT9, but not SLC5A8, in head and neck squamous cell carcinomas. Gene Chromosome Cancer 2010;49:319-26.

[123] Ogawa K, Yoshioka Y, Isohashi F, Seo Y, Yoshida K, Yamazaki H. Radiotherapy targeting cancer stem cells: current views and future perspectives. Anticancer Res 2013;33:747-54.

[124] Armstrong CA, Jones GD, Anderson R, et al. DNMTs are required for delayed genome instability caused by radiation. Epigenetics 2012;7:892-902.

[125] Koturbash I, Baker M, Loree J, et al. Epigenetic dysregulation underlies radiation-induced transgenerational genome instability in vivo. Int J Radiat Oncol Biol Phys 2006;66:327-30.

[126] Zhu B, Huang X, Chen J, Lu Y, Chen Y, Zhao J. Methylation changes of H19 gene in sperms of $\mathrm{X}$-irradiated mouse and maintenance in offspring. Biochem Biophys Res Commun 2006;340:83-9.

[127] Wagner JM, Hackanson B, Lubbert M, Jung M. Histone deacetylase (HDAC) inhibitors in recent clinical trials for cancer therapy. Clin Epigenet 2010;1:117-36.

[128] Song SH, Han SW, Bang YJ. Epigenetic-based therapies in cancer: progress to date. Drugs 2011;71:2391-403.

[129] Purrucker JC, Fricke A, Ong MF, Rube C, Rube CE, Mahlknecht U. HDAC inhibition radiosensitizes human normal tissue cells and reduces DNA double-strand break repair capacity. Oncol Rep 2010;23:263-9.

[130] De Schutter H, Nuyts S. Radiosensitizing potential of epigenetic anticance drugs. Anticancer Agent Med Chem 2009;9:99-108.

[131] Karagiannis TC, Kn H, El-Osta A. The epigenetic modifier, valproic acid, enhances radiation sensitivity. Epigenetics 2006;1:131-7.

[132] Harikrishnan KN, Karagiannis TC, Chow MZ, El-Osta A. Effect of valproic acid on radiation-induced DNA damage in euchromatic and heterochromatic compartments. Cell Cycle 2008;7:468-76.

[133] Debeb BG, Xu W, Mok H, et al. Differential radiosensitizing effect of valproic acid in differentiation versus self-renewal promoting culture conditions. Int J Radiat Oncol Biol Phys 2010;76:889-95.

[134] Khalil MA, Hrabeta J, Cipro S, Stiborova M, Vicha A, Eckschlager T. Neuroblastoma stem cells - mechanisms of chemoresistance and histonedeacetylase inhibitors. Neoplasma 2012;59:737-46.

[135] Kim HJ, Kim JH, Chie EK, Da Young P, Kim IA, Kim IH. DNMT (DNA methyltransferase) inhibitors radiosensitize human cancer cells by suppressing DNA repair activity. Radiat Oncol 2012;7:39.

136] Munshi A, Kurland JF, Nishikawa T, et al. Histone deacetylase inhibitor radiosensitize human melanoma cells by suppressing DNA repair activity. Clin Cancer Res 2005;11:4912-22.

[137] Munshi A, Tanaka T, Hobbs ML, Tucker SL, Richon VM, Meyn RE. Vorinostat, a histone deacetylase inhibitor, enhances the response of human tumor cells to 
ionizing radiation through prolongation of gamma-H2AX foci. Mol Cancer Ther 2006:5:1967-74.

[138] Camphausen K, Burgan W, Cerra M, et al. Enhanced radiation-induced cell killing and prolongation of gammaH2AX foci expression by the histone deacetylase inhibitor MS-275. Cancer Res 2004;64:316-21.

[139] Kim JH, Shin JH, Kim IH. Susceptibility and radiosensitization of human glioblastoma cells to trichostatin $\mathrm{A}$, a histone deacetylase inhibitor. Int J Radiat Oncol Biol Phys 2004;59:1174-80.

[140] Zhang Y, Jung M, Dritschilo A. Enhancement of radiation sensitivity of human squamous carcinoma cells by histone deacetylase inhibitors. Radiat Res 2004;161:667-74.

[141] Kuribayashi T, Ohara M, Sora S, Kubota N. Scriptaid, a novel histone deacetylase inhibitor, enhances the response of human tumor cells to radiation. Int J Mol Med 2010;25:25-9.

[142] Shoji M, Ninomiya I, Makino I, et al. Valproic acid, a histone deacetylase inhibitor, enhances radiosensitivity in esophageal squamous cell carcinoma. Int J Oncol 2012;40:2140-6.

[143] Arundel CM, Glicksman AS, Leith JT. Enhancement of radiation injury in human colon tumor cells by the maturational agent sodium butyrate $(\mathrm{NaB})$. Radiat Res 1985;104:443-8.

[144] Banuelos CA, Banath JP, MacPhail SH, Zhao J, Reitsema T, Olive PL. Radiosensitization by the histone deacetylase inhibitor PCI-24781. Clin Cancer Res 2007;13:6816-26.

[145] Kim IA, No M, Lee JM, et al. Epigenetic modulation of radiation response in human cancer cells with activated EGFR or HER-2 signaling: potential role of histone deacetylase 6. Radiother Oncol 2009:92:125-32.

[146] Lu YS, Chou CH, Tzen KY, et al. Radiosensitizing effect of a phenylbutyratederived histone deacetylase inhibitor in hepatocellular carcinoma. Int J Radiat Oncol Biol Phys 2012;83:e181-9.

[147] Chung YL, Lee MY, Pui NN. Epigenetic therapy using the histone deacetylase inhibitor for increasing therapeutic gain in oral cancer: prevention of radiation-induced oral mucositis and inhibition of chemical-induced oral carcinogenesis. Carcinogenesis 2009;30:1387-97.

[148] Chung YL, Wang AJ, Yao LF. Antitumor histone deacetylase inhibitors suppress cutaneous radiation syndrome: Implications for increasing therapeutic gain in cancer radiotherapy. Mol Cancer Ther 2004;3:317-25.

[149] Miller AC, Cohen S, Stewart M, Rivas R, Lison P. Radioprotection by the histone deacetylase inhibitor phenylbutyrate. Radiat Environ Biophys 2011;50:585-96.

[150] Hellebrekers DM, van Griffioen AW, Engeland M. Dual targeting of epigenetic therapy in cancer. Biochim Biophys Acta 2007;1775:76-91.

[151] Qiu H, Yashiro M, Shinto O, Matsuzaki T, Hirakawa K. DNA methyltransferase inhibitor 5-aza-CdR enhances the radiosensitivity of gastric cancer cells. Cancer Sci 2009:100:181-8.

[152] De Schutter H, Kimpe M, Isebaert S, Nuyts S. A systematic assessment of radiation dose enhancement by 5-Aza-2'-deoxycytidine and histone deacetylase inhibitors in head-and-neck squamous cell carcinoma. Int Radiat Oncol Biol Phys 2009;73:904-12.

[153] Dote H, Cerna D, Burgan WE, et al. Enhancement of in vitro and in vivo tumor cell radiosensitivity by the DNA methylation inhibitor zebularine. Clin Cance Res 2005;11:4571-9.
[154] Chan AT, Tao Q, Robertson KD, et al. Azacitidine induces demethylation of the Epstein-Barr virus genome in tumors. J Clin Oncol 2004;22:1373-81.

[155] Cho HJ, Kim SY, Kim KH, et al. The combination effect of sodium butyrate and 5-Aza-2'-deoxycytidine on radiosensitivity in RKO colorectal cancer and MCF-7 breast cancer cell lines. World J Surg Oncol 2009;7:49.

[156] Gore SD, Baylin S, Sugar E, et al. Combined DNA methyltransferase and histone deacetylase inhibition in the treatment of myeloid neoplasms. Cancer Res 2006;66:6361-9.

[157] Tsai HC, Li H, Van Neste L, et al. Transient low doses of DNA-demethylating agents exert durable antitumor effects on hematological and epithelial tumor cells. Cancer Cell 2012;21:430-46.

[158] Shen H, Laird PW. In epigenetic therapy, less is more. Cell Stem Cell 2012;10:353-4.

[159] Ward C, Langdon SP, Mullen P, et al. New strategies for targeting the hypoxic tumour microenvironment in breast cancer. Cancer Treat Rev 2013;39: 171-9.

[160] Shi H, Chen L, Wang H, et al. Synergistic induction of miR-126 by hypoxia and HDAC inhibitors in cardiac myocytes. Biochem Biophys Res Commun 2013:430:827-32.

[161] Yu J, Mi J, Wang Y, Wang A, Tian X. Regulation of radiosensitivity by HDAC inhibitor trichostatin A in the human cervical carcinoma cell line Hela. Eur J Gynaecol Oncol 2012;33:285-90.

[162] Naldini A, Filippi I, Cini E, Rodriquez M, Carraro F, Taddei M. Downregulation of hypoxia-related responses by novel antitumor histone deacetylase inhibitors in MDAMB231 breast cancer cells. Anticancer Agent Med Chem 2012:12:407-13.

[163] Ioannidis JP. Why most published research findings are false. PLoS Med 2005; $2: \mathrm{e} 124$

[164] Laird PW. Principles and challenges of genomewide DNA methylation analysis. Nat Rev Genet 2010;11:191-203.

[165] Bock C. Epigenetic biomarker development. Epigenomics 2009;1:99-110.

[166] Quon G, Haider S, Deshwar AG, Cui A, Boutros PC, Morris Q. Computational purification of individual tumor gene expression profiles leads to significant improvements in prognostic prediction. Genome Med 2013;5:29.

[167] Starmans MH, Pintilie M, John T, et al. Exploiting the noise: improving biomarkers with ensembles of data analysis methodologies. Genome Med 2012;4:84.

[168] Boutros PC, Pintilie M, John T, et al. Re: gene expression-based prognostic signatures in lung cancer: ready for clinical use? J Natl Cancer Inst 2010;102:1677-8. author reply 1678-1679.

[169] Subramanian J, Simon R. Gene expression-based prognostic signatures in lung cancer: ready for clinical use? J Natl Cancer Inst 2010;102:464-74.

[170] van Vlodrop IJ, Niessen HE, Derks S, et al. Analysis of promoter CpG island hypermethylation in cancer: location, location, location! Clin Cancer Res 2011;17:4225-31.

[171] Irizarry RA, Ladd-Acosta C, Wen B, et al. The human colon cancer methylome shows similar hypo- and hypermethylation at conserved tissue-specific CpG island shores. Nat Genet 2009;41:178-86.

[172] Frigola J, Song J, Stirzaker C, Hinshelwood RA, Peinado MA, Clark SJ. Epigenetic remodeling in colorectal cancer results in coordinate gene suppression across an entire chromosome band. Nat Genet 2006;38:540-9. 